http://doi.org/10.35784/iapgos.2168

\title{
ANALYSIS OF HEAT TRANSFER IN BUILDING PARTITIONS WITH THE USE OF COMPUTATIONAL FLUID DYNAMICS TOOLS
}

\author{
Arkadiusz Urzędowski ${ }^{1}$, Joanna Styczeń ${ }^{2}$, Magdalena Paśnikowska-Łukaszuk ${ }^{1}$ \\ ${ }^{1}$ Lublin University of Technology, Fundamentals of Technology Faculty, Lublin, Poland, ${ }^{2}$ Lublin University of Technology, Department of Electronics and Information \\ Technology, Lublin, Poland
}

Abstract. The article presents the mechanisms of heat exchange in building partitions along with a description of the phenomena occurring there. The methods of heat transport on selected examples of the construction of sandwich building walls were presented and discussed. A review of the methods allowing to determine the heat flux value by means of analytical methods and simulations based on numerical analyzes was carried out. The methodology of solving thermal problems has been presented, indicating the complexity of the phenomena occurring at the contact points of surfaces, for which the correct characteristics should be selected in more than one selected form of determining temperature distributions. Heat transport simulation was performed in ANSYS Fluent 2020 R2 software. The value of the heat flux density flowing through the outer wall of a single-family house located in Lublin, Poland was analytically determined. Three different structural wall solutions were adopted: one, two and three-layer. The obtained results were presented in a tabular manner, allowing for a clear verification of the correctness of the calculations performed with both selected methods.

Keywords: CFD, heat flux, heat transfer in multilayer walls

\section{ANALIZA TRANSPORTU CIEPLA W PRZEGRODACH BUDOWLANYCH W WYKORZYSTANIEM NARZĘDZI DO OBLICZENIOWEJ MECHANIKI PLYNÓW CFD}

Streszczenie. W artykule przedstawiono mechanizmy wymiany ciepła $w$ przegrodach budowlanych wraz z opisem zjawisk tam zachodzacych. Przybliżono $i$ omówiono sposoby transportu ciepła na wybranych przyktadach konstrukcji warstwowych ścian budowlanych. Przeprowadzono przegląd metod pozwalajacych na wyznaczenie wartości gestości strumienia ciepła na drodze metod analitycznych oraz symulacji opartych na analizach numerycznych. Przedstawiono metodologię rozwiązywania zagadnień cieplnych wskazując na złożoność zjawisk zachodzacych w miejscach kontaktu powierzchni dla których poprawnej charakterystyki należy przyjąć więcej niż jedna wybrana formę wyznaczenia rozkładów temperatury. Wykonano symulację transportu ciepła $w$ oprogramowania ANSYS Fluent 2020 R2 oraz wyznaczono analitycznie wartość gęstości strumienia ciepła przeptywajacego przez ścianę zewnętrzna domu jednorodzinnego posadowionego w Lublinie w Polsce. Przyjęto trzy różne pod względem konstrukcyjnym rozwiązania ścian: jedno, dwu i trój warstwowe. Otrzymane wyniki przedstawione zostały $w$ sposób tabelaryczny umożliwiajac przejrzysta weryfikację poprawności wykonanych obliczeń obydwoma wybranymi metodami.

Slowa kluczowe: CFD, strumień ciepła, transport ciepła w ścianach warstwowych

\section{Introduction}

The heat flux flows only in an environment with a temperature difference from places with higher temperature to places with lower temperature, until they are evened out.

Depending on the type of medium, heat exchange may take place by:

- conduction which is characteristic for solids,

- flow (convection) - characteristic for liquids and gases,

- radiation - characteristic of solids in the gaseous medium.

In materials characterized by a porous structure, heat transfer is usually complex and takes place through conduction, convection and radiation (the process take place in the pores of the materials and depends on their size). The calculation of thermal properties was based on formulas from heat conduction laws.

Conduction heat flow is the transfer of kinematic energy between the body molecules at their direct contact. In theoretical considerations of the heat transfer phenomenon by conduction, it is assumed that the solid is isotropic and the temperature changes in its various parts depend on the time $\tau$ [15]. This phenomenon can be described by the formulas resulting from Fourier's law showing the relationship between the heat flux density $\mathrm{q}$ and the temperature gradient (1) and the relationship between the temperature change over time and the temperature change in the material (2):

$$
\begin{gathered}
q=-\lambda \frac{\delta t}{\delta x} \\
\frac{\delta \mathrm{t}}{\delta \mathrm{x}}=\mathrm{a} \frac{\delta^{2} \mathrm{t}}{\delta \mathrm{x}^{2}}
\end{gathered}
$$

Heat flow by convection takes place in gaseous and liquid media, i.e. in an environment in which the molecules are in the motion due to local heating or cooling, and it may occure in limited and unlimited spaces. The intensity of heat exchange by free convection caused by the difference in air density in the boundary zone between the layers is relatively low, but it can be increased by causing mechanical gas movement - forced convection [15]. The phenomena based on the principle of free laminar convection occur in the gaps and air pores of the contact of materials in laered structures.

$$
q_{k}=\alpha_{k}\left(t_{c}-t_{F}\right)
$$

The heat exchange by convection is described by Newton's law: where:

$\mathrm{q}_{\mathrm{k}}$ - density of the heat flux flowing between the medium and the surface, $\mathrm{W} / \mathrm{m}^{2}$

$\alpha_{\mathrm{k}}-$ coefficient of heat transfer by convection, $\mathrm{W} / \mathrm{m}^{2} \mathrm{~K}$

$\mathrm{t}_{\mathrm{c}}$ - temperature of the centre, ${ }^{\circ} \mathrm{C}$

$\mathrm{t}_{\mathrm{F}}$ - surface temperature, ${ }^{\circ} \mathrm{C}$

Heat transfer by radiation is the transfer of energy between two bodies in a vacuum or gaseous medium via electromagnetic waves. This phenomenon can be divided into 2 phases: change of thermal energy into electromagnetic energy, conversion of electromagnetic energy into thermal energy. The radiation source is all bodies with a temperature greater than absolute zero, and its intensity depends on their temperature, radiation capacity, absorption and reflection, shape, size and mutual position [15]. A body which at a assigned temperature achieves the maximum capacity to radiate heat is called a perfectly black body. The total energy of $\mathrm{Q}_{0}$ radiation reaching the body surface is described by the formula:

$$
Q_{o}=Q_{\varepsilon}+Q_{\rho}+Q_{\eta}
$$

where:

$\mathrm{Q} \varepsilon-$ part of the energy absorbed by the body,

$\mathrm{Q} \rho-$ part of the energy reflected from the body,

$\mathrm{Q} \eta-$ part of the energy passing through the body. 


\section{Solving problems of heat transport}

The process of solving issues related to heat transfer usually follows the following scheme [13]:

- determination of the physical model of the phenomenon,

- preparation of a mathematical model of the phenomenon,

- selection of the solution method: analytical, numerical or experimental,

- selection of the method of solving the problem among analytical, numerical or experimental methods,

- acceptance of numerical data necessary to solve a specific problem,

- implementation of the selected method of solving the problem,

- preparation of results in the form of formulas, tables or charts,

- analysis of the obtained results in terms of physical interpretation and accuracy,

- use of the obtained results for specific technical calculations.

\subsection{Analytical solution to the problem of heat transport}

For a limited number of problem types, it is possible to solve thermal problems with analytical methods. Analytical methods give results in the form of mathematical formulas that are accurate for simple heat transfer problems [1, 13]. With complex shapes and boundary conditions, analytical solutions require simplifications regarding the regular shape of the area, "simple" boundary conditions, assumptions of homogeneity, and considering a one-dimensional task. Regardless of these limitations, the possibility of referring to the analytical solution is very valuable in the process of verifying the approximate solution.

The heat conduction equation for isotropic bodies can be written as:

$$
\frac{\partial}{\partial x}\left(\lambda \frac{\partial T}{\partial x}\right)+\frac{\partial}{\partial y}\left(\lambda \frac{\partial T}{\partial y}\right)+\frac{\partial}{\partial y}\left(\lambda \frac{\partial T}{\partial y}\right)+\frac{\dot{q}}{\lambda}=\frac{1}{\alpha} \frac{\partial T}{\partial \tau}
$$

Where:

$\mathrm{x}, \mathrm{y}, \mathrm{z}$ - coordinates,

$\lambda$ - thermal conductivity coefficient, $\mathrm{W} / \mathrm{mK}$

$\mathrm{T}$ - temperature, $\mathrm{K}$

$\mathrm{q}^{\cdot}$ - internal heat source, $\mathrm{W} / \mathrm{m}^{3}$

$\partial$ - density, $\mathrm{kg} / \mathrm{m}^{3}$

$\tau$ - time,

$\alpha-$ thermal diffusivity.

To solve this equation, it is necessary to determine the initial conditions that define the state of the system at the initial moment at each point, and the boundary conditions that describe the behavior of the functions on the edge of the area $[1,4,14]$. There are three types of boundary conditions:

- the first type of boundary condition (Dirichlet) - the temperature distribution at all points of the body surface is known,

- the second type of boundary condition (Neuman) - the heat flux density distribution $\mathrm{q}$ is known at all points of the body surface, the wall temperature $T_{S}$ is unknown,

- boundary condition of the third type - the temperature of the fluid $T_{p}$ surrounding the solid is given and the heat transfer coefficient, the temperature of the wall surface $\mathrm{T}_{\mathrm{S}}$ is unknown.

The law of heat conduction, also known as Fourier's law, states that the time rate of heat transfer through a material is proportional to the negative gradient in the temperature and to the area, at right angles to that gradient, through which the heat flows:

$$
q=-\lambda \Delta T=-\lambda \frac{d T}{d x}
$$

where:

$\mathrm{q}$ - local heat flux density $\left[\mathrm{W} / \mathrm{m}^{2}\right]$,

$\lambda$ - material conductivity $[\mathrm{W} / \mathrm{mK}]$,

$\Delta \mathrm{T}=\mathrm{dT} / \mathrm{dx}$ - temperature gradient $[\mathrm{K} / \mathrm{m}]$.

Thermal resistance is a heat property and a measurement of a temperature difference by which an object or material resists a heat flow. Thermal resistance is the reciprocal of thermal conductance. Jest as an electrical resistance is associated with the conduction of electricity, a thermal resistance may be associated with the conduction of heat. Then Fourier's law of heat conduction for the wall can be expressed as:

$$
Q_{\text {wall }}=-\lambda A \frac{T_{2}-T_{1}}{L}=-\frac{T_{2}-T_{1}}{R_{\text {thcond }}}
$$

where:

$\Delta \mathrm{T}-$ the amount of heat which transits through the structure $\left(\mathrm{T}_{2}-\mathrm{T}_{1}\right)$

$\mathrm{R}_{\text {thcond }}$ - the thermal conductive resistance, in this case

$\mathrm{R}_{\text {thcond }}=\mathrm{L} / \lambda_{\mathrm{L}} \mathrm{A}$,

$\mathrm{L}$ - length,

A - area,

$\lambda_{\mathrm{L}}-$ the thermal conductivity in the length direction.

\subsection{Numerical solution to the problem of heat transport}

Numerical calculations require discretization of the area, which is associated with the departure from the original equation and its exact solution in favour of determining an approximate solution in a finite number of points. However, they make it possible to take into account complex shapes and boundary conditions as well as the dependence of material properties from temperature. Among the methods used to solve equations numerically, there are three groups, they are: the finite difference method, the finite element method, and the finite volume method [9].

The finite difference method consists in changing the differential operators to the appropriate difference operators, defined on a discrete set of isolated points.

$$
\frac{d f}{d x}=\lim _{\Delta x \rightarrow 0} \frac{f(x+\Delta x)-f(x-\Delta x)}{2 \Delta x}
$$

Due to the approximation of the function and its derivatives, the initial boundary problem is reduced to a system of algebraic equations in which the unknowns are the discrete values of the function. In the case of calculations considered for twodimensional areas, they are divided into squares, and for 3D into cubes. Due to the requirement of regularity, mapping areas of complex shape is not a simple matter. By inserting the difference quotients into equation 8 for the two-dimensional temperature field (Fig. 2), the following equation is obtained:

$$
\frac{T_{m-1, n}-2 T_{m, n}+T_{m+1, n}}{\Delta x^{2}}+\frac{T_{m, n+1}-2 T_{m, n}+T_{m, n-1}}{\Delta y^{2}}+\frac{q_{\dot{m}, n}}{\lambda}=0
$$

Where $\mathrm{m}$ is the number of the next node $\mathrm{m}=1,2,3 . ., \mathrm{m}-1$.

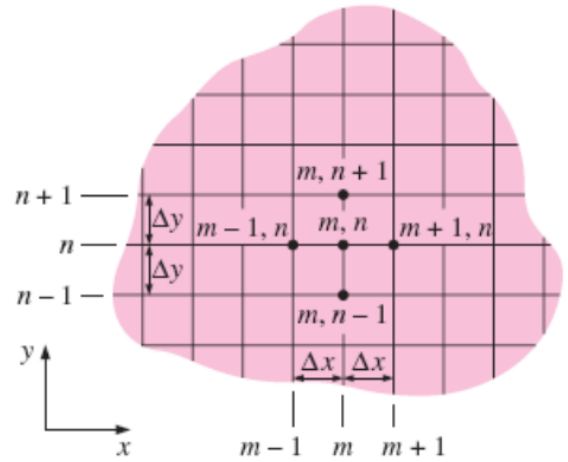

Fig. 1. Calculation of temperature in nodes for the $2 D$ case

Considering the phenomena occurring at the interface in layer structures, these equations must be determined for mesh nodes in solids and air pores, taking into account the irregularities of the surface shape. Due to the high degree of difficulty of solving so many complex equations, computer fluid mechanics (CFD) programs such as ANAYS Fluent, Autodesk CFD Ultimate and Altair FLUX are commonly used $[2,5,11]$. 


\section{Methods}

The paper presents an analysis of heat transport in building partitions using the analytical and numerical method with the use of CFD computational fluid mechanics tools. The object of research is the outer wall of a single-story single-family residential building. The wall area is $35 \mathrm{~m}^{2}$, where its length is $10 \mathrm{~m}$ and height is $3.5 \mathrm{~m}$. The thickness of the partition depends on its construction and three solutions were selected for the research:

- a single-layer wall $0.44 \mathrm{~m}$ thick, consisting of Porotherm 44T Profi ceramic hollow bricks,

- a two-layer wall with a thickness of $0.39 \mathrm{~m}$, consisting of $0.24 \mathrm{~m}$ Ytong Forte concrete blocks and thermal insulation expanded polystyrene boards „Termo Organika Fasada Dalmatyńczyk $15 \mathrm{~cm}$,

- a three-layer wall with a thickness of $0.56 \mathrm{~m}$, consisting of solid ceramic brick, thickness: $0.25 \mathrm{~m}$, thermal insulation in the form of expanded polystyrene panels $0.16 \mathrm{~m}$ thick „Termo Organika Termonimium Plus Fasada”, $0.03 \mathrm{~m}$ closed air gap and $0.12 \mathrm{~m}$ facade layer form consisting of solid ceramic brick

All three partitions had to meet the criteria for the maximum values of the heat transfer coefficient $\mathrm{U}_{\mathrm{C}}(\max )\left[\mathrm{W} / \mathrm{m}^{2} \mathrm{~K}\right]$ applicable from January 2021 for external walls for a heated room with a temperature of $\mathrm{t}_{\mathrm{i}} \geq 16^{\circ} \mathrm{C}$, specified in Journal of Laws No. 2013 item 926 Regulation of the Minister of Transport, Construction and Maritime Economy of 5 July 2013 amending the regulation on technical conditions to be met by buildings and their location [3]. The resulting maximum permissible value of the heat transfer coefficient is $0.20 \mathrm{~W} / \mathrm{m}^{2} \mathrm{~K}$, however, for the purposes of the research, it was assumed in the article that it would be about $0.17 \mathrm{~W} / \mathrm{m}^{2} \mathrm{~K}$

The value of the thermal conductivity coefficient $\lambda[\mathrm{W} / \mathrm{mK}]$ of materials was taken from the catalogs of manufacturers of selected building materials, and the calculations of the heat transfer coefficient were carried out in accordance with PN-EN ISO 6946: 2008 Building components and building elements - Thermal resistance and heat transfer coefficient - Calculation method [8], where the heat transfer coefficient is expressed by the equation:

$$
U=\frac{1}{R_{T}}
$$

where:

$$
R_{T}=R_{s i}+R_{1}+R_{2}+\cdots+R_{n}+R_{s e}
$$

where:

$\mathrm{R}_{\mathrm{si}}$ - resistance to heat transfer on the inner surface,

$R_{1}, R_{2} \ldots R_{n}$ - design thermal resistance of each layer,

$\mathrm{R}_{\mathrm{se}}-$ resistance to heat transfer on the outer surface.

Temperature values were assumed $\mathrm{T}_{1}=-20^{\circ} \mathrm{C}$ on the outer side of the building partition, read from maps for the 3rd climate zone in Poland, in which the city of Lublin is located, according to Table NB.1 of the norm PN-EN 12831 „Heating installations in buildings, Method for calculating the design heat load" [7], corresponding to the design air temperature outside the building in accordance with PN-82 / B-02403 [6]. The internal temperature $\mathrm{T}_{2}=20^{\circ} \mathrm{C}$ was adopted on the basis of the same standard, Table NB.2 [7], as the design temperature for rooms intended for permanent stay of people without external covers, not performing continuous physical work.

Formulas 7 and 8 were used in the analytical calculations, while the ANSYS Fluent 2020 R2 program was used to model and simulate heat transport phenomena $[10,12]$. The assumed heat transport simulation process was as follows:

- starting work in the Ansys Wrokbench environment with the Steady-State Thermal module,

- generating geometry in the New Design Modeler Geometry environment,
- adding new materials with assigned previously determined values of the thermal conductivity coefficient $\lambda$ in the Engeenering Data module (Fig. 2),

- editing the solid in the Model environment: discretization of the mesh, assigning the initial conditions on the wall surfaces: $\mathrm{T}_{1}=-20^{\circ} \mathrm{C}, \mathrm{T}_{2}=20^{\circ} \mathrm{C}$, simulating heat transport,

- evaluation of the results and reading the heat flux density values.

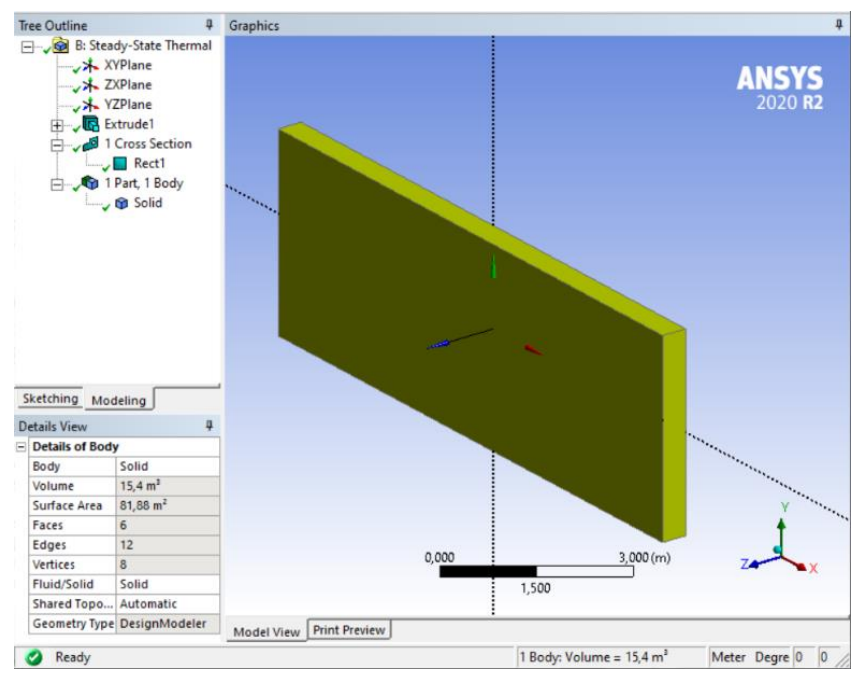

Fig. 2. The process of modeling a partition and assigning materials with a given value of the thermal conductivity coefficient in the ANSYS environment

\section{Results}

The determination of the heat flux density in the steady state was carried out using the analytical method in accordance with the formulas No. 6 and 7. The construction material adopted for a single-layer wall is a polished ceramic block filled with mineral wool, intended for the construction of external single-layer walls without insulation, built with a thin-jointed mortar. This solution allows to meet the criteria included in the technical conditions applicable to residential buildings from January 2021 [3]. The physical parameters of the selected single-layer partition are: width: $10 \mathrm{~m}$, hight: $3.5 \mathrm{~m}$, thickness of partition: $\mathrm{L}=0.44 \mathrm{~m}$, area of wall: $\mathrm{A}=35 \mathrm{~m}^{2}$, capacity: $15.4 \mathrm{~m}^{3}$, thermal conductivity: $\lambda_{\mathrm{L}}=0.17 \mathrm{~W} / \mathrm{mK}$, temperature gradient: $\Delta \mathrm{T}=40^{\circ} \mathrm{C}$.

After substituting these values in formula no. 7, we get:

$$
\begin{gathered}
Q_{\text {1layerwall }}=-\lambda_{L} A \frac{T_{2}-T_{1}}{\mathrm{~L}}=-0.17 \cdot 35 \cdot \frac{40}{0.44} \\
=540.909 \mathrm{~W}
\end{gathered}
$$

In the ANSYS environment, the discretization of the mesh for a given solid was carried out and the value of the heat transfer coefficient $\lambda_{\mathrm{L}}=0.17 \mathrm{~W} / \mathrm{mK}$ was implemented in the modeled partition fragment, and then the process of simulating heat transport in a steady state was started.

As a result, a graphic representation of the temperature distribution in the partition was obtained (Fig. 3). Moreover, the value of the heat flux density was determined, which for a singlelayer wall was $\mathrm{Q}=540.91 \mathrm{~W}$. The same value was obtained as a result of calculations carried out with the analytical method.

Calculations and simulations of heat transport in the remaining selected two and three-layer building partitions were performed. The results obtained with each of these methods coincided, which proves the correctness of the selected method of conducting analyzes with the use of computer fluid mechanics tools in the ANSYS environment and the adopted methodology of analytical solutions. These results have been collected and presented in tabular form in Table 1, where the cross-sections of each of the adopted construction solutions for building partitions are also presented graphically. 


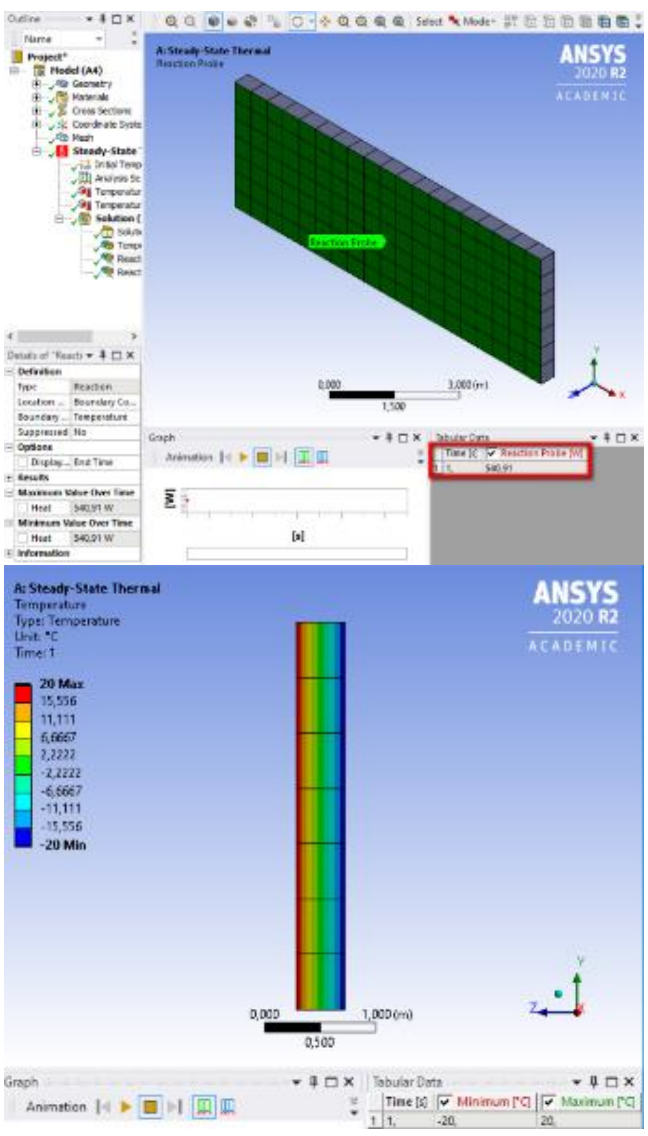

Fig. 3. Graphical representation of the temperature distribution in the partition and the result of the simulations

Table 1. Determined values of heat flux density for one, two and three-layer partitions

\begin{tabular}{|c|c|c|c|c|c|}
\hline Paramater & Symbol & Unit & 1 layer wall & 2 layer wall & 3 layer wall \\
\hline $\begin{array}{c}\text { Thickness } \\
\text { of partition }\end{array}$ & $\mathrm{L}$ & $\mathrm{m}$ & 0.440 & 0.390 & 0.560 \\
\hline Area of wall & $\mathrm{A}$ & $\mathrm{m}^{2}$ & 35.000 & 35.000 & 35.000 \\
\hline $\begin{array}{c}\text { Thermal } \\
\text { conductivity }\end{array}$ & $\lambda_{\mathrm{L}}$ & $\mathrm{W} / \mathrm{mK}$ & 0.170 & 0.173 & 0.166 \\
\hline $\begin{array}{c}\text { Temperature } \\
\text { Gradient }\end{array}$ & $\Delta \mathrm{T}$ & ${ }^{\circ} \mathrm{C}$ & 40.000 & 40.000 & 40.000 \\
\hline Heat flux & Qwall & $\mathrm{W}$ & -540.910 & -621.030 & -415.750 \\
\hline
\end{tabular}

\section{Summary and conclusions}

Based on the research, the following conclusions were drawn:

- the results obtained with both the numerical and analytical methods coincide, which indicates the correctness of the adopted methodologies,

- the highest value of the heat flux density was obtained for a wall with a two-layer structure with a thickness of $0.39 \mathrm{~m}$ and it was $621.03 \mathrm{~W}$, while the lowest for a three-layer wall was $415.75 \mathrm{~W}$

- the heat flux density in the adopted models depends inversely on the wall thickness,

- computational fluid dynamics tools significantly facilitate the calculation of heat transport,

- numerical methods have an advantage over analytical calculations, because other experiments can be performed very efficiently on the already created models by changing only single selected parameters,

- methods based on computational fluid dynamics require very good knowledge of the selected software,

- it is advisable to carry out tests using both methods to check their correctness and not to rely only on computer software.

\section{References}

[1] Barnat-Hunek D., Lagod G., Klimek B.: Evaluation of the contact angle and frost resistance of hydrophobised heat-insulating mortars with polystyrene. AIP Conference Proceedings 1866, 2017, 040004

[2] Chong H., Wang H., Li E.: Update-grid reanalysis method based on NS-FEM for 3D heat transfer problems. Eng. Anal. Bound. Elem. 95/2018, 142-153, https://doi.org/10.1016/j.enganabound.2018.07.010].

[3] Dz.U. 2013 poz. 926.: Rozporządzenie Ministra Transportu, Budownictwa i Gospodarki Morskiej z dnia 5 lipca 2013 r.

[4] Furmański P., Domański R.: Wymiana ciepła. Przykłady obliczeń i zadania. Oficyna Wydawnicza Politechniki Warszawskiej, Warszawa 2002

[5] Li Z. C., Cui X. Y., Cai Y.: Analysis of heat transfer problems using a nove low-order FEM based on gradient weighted operation. Int. J. Therm. Sci. 132/2018, 52-64, [https://doi.org/10.1016/j.ijthermalsci.2018.05.039].

[6] PN-82 / B-02402.: Ogrzewnictwo - Temperatury ogrzewanych pomieszczeń w budynkach.

[7] PN-EN 12831:2006.: Instalacje ogrzewcze w budynkach. Metoda obliczania projektowego obciążenia cieplnego.

[8] PN-EN ISO 6946.: Komponenty budowlane i elementy budynku Opór cieplny i współczynnik przenikania ciepła Metoda obliczania.

[9] Raczkowski A., Suchorab Z., Czechowska-Kosacka A.: Computational fluid dynamics simulation of an earth-air heat exchanger for ventilation system, AIP Conference Proceedings 1866, 2017, 040032.

[10] Saleem A., Farooq S., Karimi I. A., Banerjee R.: Wall superheat at the incipient nucleate boiling condition for natural and forced convection: A CFD approach, Comput. Chem. Eng. 134/2020, 106718, [https://doi.org/10.1016/j.compchemeng.2019.106718].

[11] Sheikholeslami M., Ghasemi A.: Solidification heat transfer of nanofluid in existence of thermal radiation by means of FEM. Int. J. Heat Mass Transf. 123/2018, 418-431.

[12] Takabatake K., Sakai M.: Flexible discretization technique for DEM-CFD simulations including thin walls. Adv. Powder Technol. 31(5)/2020, 1825-1837, [https://doi.org/10.1016/j.apt.2020.02.017]

[13] Wiśniewski S., Wiśniewski T. S.: Wymiana ciepła. Wydawnictwa NaukowoTechniczne, Warszawa 2000

[14] Wójcicka-Migasiuk D.: Analiza wymiany ciepła w ścianach słonecznych. Lubelskie Towarzystwo Naukowe, Lublin 2008.

[15] Żenczykowski W.: Budownictwo ogólne. Problemy fizyki budowli i instalacje. Arkady, Częstochowa 1987

\section{M.Sc. Arkadiusz Urzędowski}

e-mail: a.urzedowski@pollub.pl

Postgraduate student of department of Civil Engineering and Architecture Faculty, Fundamentals of Technology Faculty and Electrical Engineering and Computer Science Faculty at Lublin University of Technology. Author of 24 scientific work. Research interest is heat transport phenomena in microstructures of building materials, computer-aided design, building information modeling.

http://orcid.org/0000-0002-0440-3013

\section{M.Sc. Eng. Joanna Stycze}

e-mail: j.styczen@pollub.pl

Assistant in the Department of Construction at the Faculty of Building and Architecture of the Lublin University of Technology. Scientific research, includes the impact of zeolites on the cement hydration process and use of zeolites in renovation plasters.

http://orcid.org/0000-0001-7325-5045

\section{M.Sc. Magdalena Paśnikowska-Łukaszuk} e-mail: m.pasnikowska-lukaszuk@pollub.pl

Graduate of Fundamentals of Technology Faculty at Lublin University of Technology. Author of 24 scientific work. Research interest is environmental engineering, power engineering and IT and telecommunications.

http://orcid.org/0000-0002-3479-6188
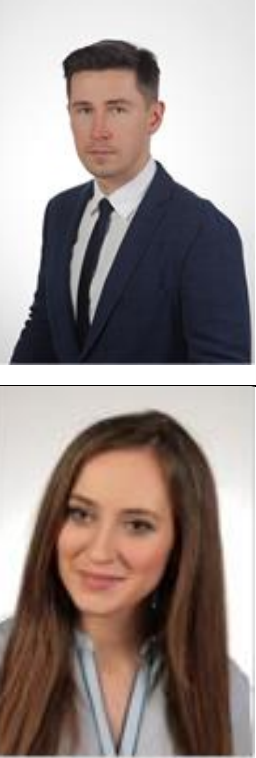

otrzymano/received: 11.08 .2020 